Georges Bériachvili

Stanislas High School, Paris

France

Tbilisi State Conservatoire

Georgia
UDC 781

78.038

doi: $10.5937 / Z b A k U 2008053 B$

Original scientific paper

\title{
Musical Gesture and Phenomenology of Musical Space in 20th-Century Avant-Garde Music
}

Abstract: In the present paper I propose a conceptual framework that establishes a link between two fundamental concepts of music theory: musical gesture and musical space. The unfolding in time is a fundamental feature of musical gesture. However, in plastic arts, the gesture can only be represented in a spatial form. Since music possesses its own internal space, it is logical to assume that musical space can also carry spatialized gestural „imprints“. To describe such indirect manifestations of gesture, I introduce the concept of spatial imprint of musical gesture (SIMG). This concept entails a phenomenological approach to musical space, accordingly to which, the phenomenon of musical space includes all forms of quasi-spatial mental representations of music itself, and excludes all abstract representations like „pitch space“, „,space“ of parameter values, schemes of formal structure, etc.

I single out five general aspects of the musical space phenomenon:

- Quasi-geometric space: a mental representation of music, based on the analytical spatial vision of its elements (sounds, layers, figures, shapes, etc.).

- Space as sound substance: an association of sound with color, light, material, physical properties of substances, etc.

- Energetic space: a quasi-spatial representation of forces acting within the musical process.

- Synthetic large-scale temporal space.

- Physical space.

These types of spatial representations generally coexist, but one of them may acquire a leading role in certain styles. The development of the art music during past century placed a priority on three components: quasi-geometrical space, space as substance, and physical space. Quoting works by Schönberg, Webern, Stockhausen, Xenakis, and Ligeti, I consider some paradigmatic examples, in which the SIMG becomes a key element from technical and aesthetic standpoints.

In the last part of the paper I present a hypothesis, according to which, the process of „spatialization" of music and ,migration“ of gesture to musical space could be a result of 
cultural trauma. This trauma consists of the distrust of human communion and cathartic consolation through direct empathy, or, more broadly, in a distrust of Humanism.

Keywords: musical gesture, musical space, embodied music cognition, avant-garde music, musical time (linearity/nonlinearity).

\section{Introduction}

During the last three decades, studies on musical gesture and embodied cognition established themselves among the most promising fields of music research. One of the most attractive features of these studies is their interdisciplinarity, involving domains such as theory and history of music, psychology, neuroscience, semiotics, and computer technologies. In view of works published to date, this corpus has the potential to become a core of future synthetic knowledge about music.

In the present paper I will try to provide some elements that might inform future insights on this topic. First, I propose a conceptual framework, aiming to define some important characteristics of musical gesture perception in tonal and in atonal music. In books and articles on musical gesture, one can find analytical examples of diverse musical styles, including tonal, atonal and electroacoustic music. They all highlight the importance of expressive, semantic, or structural functions of gestural elements. However, none of them, as far as I know, focus on the nature of difference between the perception of musical gesture in tonal and atonal musical contexts.

To specify from the outset what kind of difference I mean, let us compare the opening measures of Haydn's String Quartet in E-flat major Op. 76 No. 6 (Ex. 1) and Webern's Quartet for clarinet, tenor saxophone, violin, and piano Op. 22 (Ex. 2). Both pieces begin with a succession of figures delimited by rests. Without going into detailed musical analysis, let us consider the characteristics of embodied perception in these passages.

It is obvious that an embodied perception of Haydn's music is farmore accessible than that of Webern's piece. In Arnie Cox's (2016) terms, the mimetic invitation ${ }^{1}$ in the case of the Haydn is quite overt, and the mimetic motor imagery (MMI) ${ }^{2}$ finds support easily in different domains of motor experience: music, dance, pantomime,

1 According to Cox, mimetic invitation is a sort of invitation ,to move, sing, and/or play along in some congruent [with music] way, whether overtly or only in imagery“ (Cox, 2016: 47). „Composers most often create the mimetic invitation, or at least a schema for it“ (ibid.), and ,performers realize, shape, and/ or extend the mimetic invitation" (ibid.).

2 Mimetic motor imagery is defined as muscle-related brain processes related to music (while listening, performing, composing, or thinking about) that do not manifest in overt actions. It includes ,not only voluntary and conscious forms, but especially those forms that occur automatically and with or without our awareness" (Cox, 2016: 12). 
dialogic affective interaction, etc. This is due to a number of factors, including tonal and rhythmical predictability, familiarity of harmonic and melodic elements, singability, and danceability.

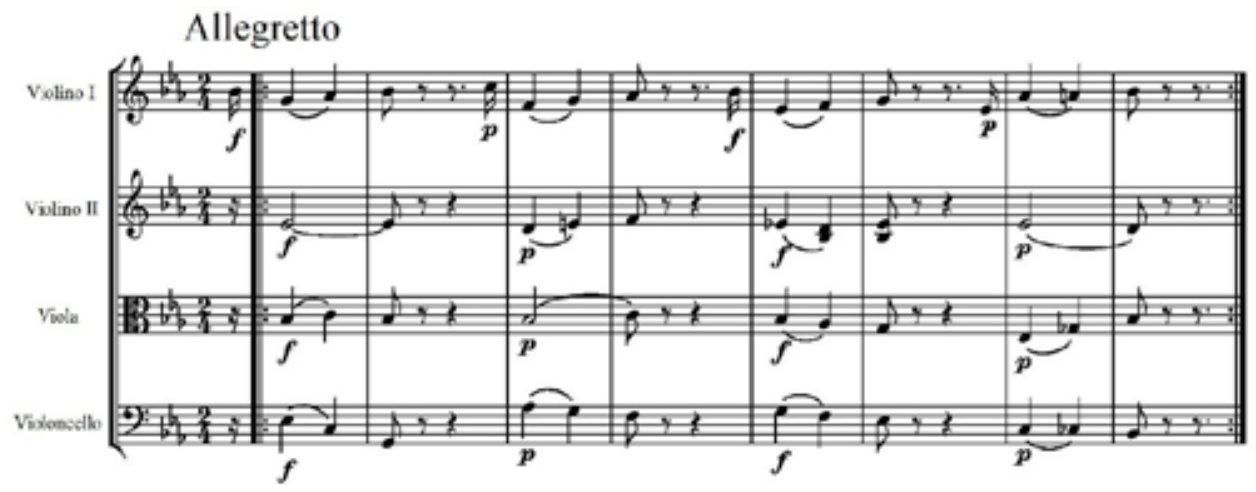

Example 1. Joseph Haydn: String Quartet in E-flat major Op. 76 No. 6 (1797), beginning.

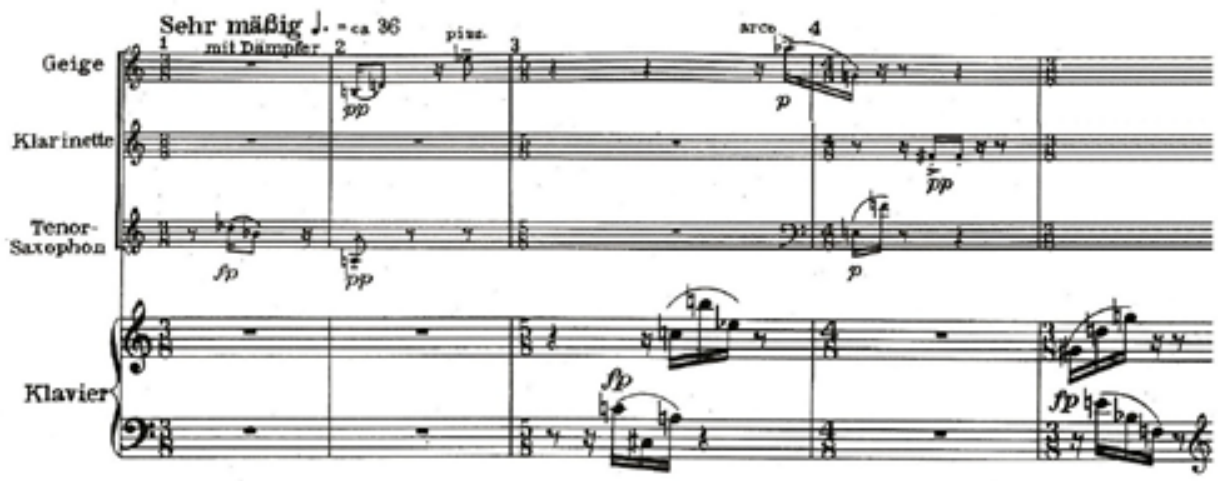

https://vimeo.com/402069595

Example 2. Anton von Webern: Quartet for clarinet, tenor saxophone, violin, and piano Op. 22 (1928-1930), beginning.

https://vimeo.com/402072748

In contrast, in Webern's dodecaphonic piece, with its almost unpredictable melodic and rhythmic evolution, unfamiliar harmonic relationships, etc., the mimetic invitation is attenuated and the activation of the mimetic motor imagery requires great concentration and a deep cultural awareness. In other words, this music is just more „cerebral“" or ,intellectual“". 
All these claims fall completely within Arnie Cox's theory. My additional observation, however, is that the mimetic invitation in the Webernian succession is not simply attenuated, but it implies a kind of imaginary ,interface“: a quasi-spatial vision of music. This means that the embodied perception of Webern's music requires not only hearing, but also a kind of mental ,seeing“ - a visualization of figures as moving „objects“ with specific gestural shapes.

I do not mean a score-like two-dimensional representation that can be imagined by advanced musicians, but rather a kind of „three-dimensional“ image, which is unique to each listener and more or less precise. These moving images help not only to identify the musical texture and progression, but also to „recover" the embodied meaning of figures. This perceptive mechanism is important for complex tonal textures as well, but in atonal music it is particularly crucial. For a deeper understanding of this mechanism I coined the concept of spatial imprint of musical gesture (Bériachvili, 2009, 2010, 2013, 2018). Before I introduce this concept here, however, it is necessary to present the definitions of musical gesture and musical space that underlie my work.

\section{Concepts of musical gesture and musical space}

Regarding the concept of musical gesture, I rely on by Robert Hatten's succinct and now classic definition of ,gesture as significant energetic shaping through time“ (Hatten, 2004: 95). Of course, the main channel of gestural communication in music is the aural channel. Aural gesture can encompass, through different kinds of cross-modal associations, all of our gestural experiences in principle. The effect of aural gesture can be further reinforced by different visually perceptible elements, especially by the performer's physical gesture.

In academic studies, musical gesture is defined much more clearly than musical space. To this day, we have no sufficiently universal and authoritative approach that could define an all-encompassing concept of musical space. Lacking such a definition, I will use an approach that I developed in my own work (Bériachvili, 2009, 2010, 2018). My approach is phenomenological, since it focuses on musical space as phenomenon, i. e. ,as it appears in our experience“ (Smith, 2018). From this standpoint, musical space is a quasi-spatial mental representation of music as we actually experience it in both the technical and aesthetic sense. ${ }^{3}$

\footnotetext{
3 In music research, approaches that refer to phenomenology are numerous and very diverse (Lochhead, 2019). The definition of my work in this broad context would far exceed the scope of this paper. I shall only point out that my approach focuses on the lived experience of perception and mental representation of music, without addressing the specific concepts and methods of phenomenological philosophy.
} 
Thus, according to my approach, the concept of musical space embraces all forms of quasi-spatial mental representations of music itself, and excludes all abstract representations like ,pitch space“ (set of all usable pitches), „space“ of parameter values, schemes of formal structure, etc.

After studying a great number of texts by theorists, composers, and performers using the term „musical space“ (or similar expressions), I singled out five general categories of spatial representations of music that we can call aspects of the musical space phenomenon:

1. Quasi-geometric space: a mental representation of music, based on the analytical spatial vision of its elements (sounds, layers, figures, shapes, etc.).

2. Space as sound substance: an association of sound with color, light, material, physical properties of substances, etc.

3. Energetic space: a quasi-spatial representation of forces (or „energies") acting within the musical process, for example, tonal attraction and gravity.

4. Large-scale temporal space: a synthetic representation of an entire composition or its large segments.

5. Physical space, when it represents a significant musical element, as occurs often in electroacoustic music, or in certain instrumental pieces such as Stockhausen's Gruppen or Xenakis's Terretektorh.

Note that these five aspects are not on the same level nor do they form a hierarchy.

Categories 1-3 represent primary aspects of musical space; No. 4 refers to higher order representations incorporating all other aspects; and No. 5 is an additional category, which corresponds to a sort of „holographic“ extension of the quasi-geometric space (No. 1) and of the sound substance (No. 2). In addition, while these aspects of musical space generally coexist, one of them may acquire a leading role in certain styles. For example, the quasi-geometric space is crucial in Webern's twelve-tone period or in serial music of the 1950s, while the space-as-substance predominates in many works by Xenakis or Ligeti.

\section{Spatial imprint of musical gesture}

The simplest way to introduce the concept of spatial imprint of musical gesture (SIMG) is to compare music to plastic arts. In music, the expressive gesture naturally unfolds in time. However, in plastic arts, the gesture can only be represented in a spatial, „frozen" form - whether it is the gesture of a figure or of a painter's brush, the gesture captured by means of color, of lighting, or of the global plan of a composition. The viewer perceives these immobilized gestures and recovers their temporal and energetic substance via imagination. 
Since music possesses its own internal space, it is logical to assume that musical space can also carry such indirect manifestations of gesture, or what I call SIMG. Unlike the temporal (,direct" or ,immediate“) gesture, the perception of SIMG is mediated through musical space.

Any aspect of musical space described above can provide support for gesture:

As an example of quasi-geometric SIMG we can quote the beginning of Webern's Op. 22;

A typical example of SIMG in sound substance is the Schönbergian Klangfarbenmelodie in his orchestral piece „Farben“ Op. 16 No. 3;

The representation of energetic space is necessarily based on SIMG, because the ,energies“ are nothing but the embodied experience of musical tensions and dynamic processes;

The large-scale temporal space incorporates all other categories and therefore it includes the SIMG;

The physical space is, in fact, a three-dimensional materialization of a quasigeometric space and of sound substance; thus it can also carry SIMG.

It should be noted that the spatial aspect of musical gesture was already noticed by a number of theorists. One of the most obvious examples is Robert Hatten, according to whom „Prototypical gestures (those that occur in the perceptual present of working memory) have aspects of both object and event and thus integrate two syntheses of perception: the qualitative depth of an imagistic gestalt [...] and the continuity of a temporal gestalt [...]" (Hatten, 2004: 106, emphasis in original). Further on, Hatten speaks about ,gesture under a fermata“, which is ,akin to posture“ (2004: 126), and in his recent book A Theory of Virtual Agency (2018), we come across the wording „sonic event trace“ $(2018: 19)^{4}$. Another interesting example is that of Michel Imberty, who sees in musical form a ,projection" of human body and gesture (Imberty, 2005: 91, 93). However, even though we have such examples, no theory focuses specifically on the spatial perception of musical gesture in systematic, historical and psychological perspectives.

The main difficulty in differentiating between a direct and a mediated perception of gesture is that it is impossible to establish a clear and unambiguous boundary between the two. On the one hand, any musical gesture can be seen mentally as a spatial imprint. It is sufficient to think about a trace of a motive in our mind immediately after hearing it. If we take as an example the beginning of Haydn's E-flat major Quartet quoted above, the trace in our memory of each of the four-note motives, in the process of listening, will appear to us as a SIMG, i. e. as specific gestural shape captured as a sort of whole 4 On top of all this, Hatten's definition of gesture (,significant energetic shaping through time“, 2004: 95) contains the term ,shaping" that belongs to ,spatial“ vocabulary. 
image. This experience seems to be accessible not only to professional musicians but also to any attentive and relatively competent listener. On the other hand, any music that we perceive primarily in a quasi-spatial mode, for example many early works by Boulez, Stockhausen, Ligeti or Xenakis, possesses a temporal aspect and is performed by musicians who actually unfold musical gestures in time, i. e. in „direct" mode.

Therefore, we cannot firmly associate a musical piece or fragment to one mode of perception. The direct and mediated modes can seemingly switch and coexist and it is highly unlikely that neuroscience would be able to distinguish these modes with precision, because of their constant blending and mutual codependence.

So, we have to answer the question: are such sophisticated and intangible concepts useful to us? My answer is yes, for two main reasons. First, the concept of SIMG describes an actual existing psychological experience of music and it can be useful to explain certain elements of perception, even in more familiar tonal music. For example, in rich polyphonic textures of tonal music, the perception of the leading voice or of the overall musical progression is accompanied by the perception of accompanying contrapuntal elements in SIMG mode. Second, the concept of SIMG is important for avant-garde music theory, history, and aesthetics. It is also helpful as a pedagogical tool while presenting different avant-garde composers and deepening students' aesthetic experiences. Below I shall discuss mainly the theoretical and historical issues.

\section{Musical space, time, and gesture in tonal and atonal music}

In tonal music, all aspects of musical space are present, except the physical space, which occurs extremely rarely. ${ }^{5}$ However, ever since aesthetic thought adopted a division into spatial and temporal arts - i. e. since Lessing's Laocoon (1766) - music was unequivocally classified as a temporal art and no one questioned this opinion until the second half of the $20^{\text {th }}$ century. ${ }^{6}$ This is not only because music physically unfolds in time, but also because the inner experience of tonal music is essentially the experience of a temporal emotional stream. The spatial and architectonic aspects in tonal music are of course important, but its core, or its primitive material, remains directly gestural, i. e. unfolding the emotion in time.

5 Some famous examples: St Matthew Passion by Bach, Notturno K.286 and Serenata Notturna K.239 by Mozart, Grande symphonie funèbre et triomphale and Requiem by Berlioz.

6 Adorno's idea of ,pseudomorphism of painting in music” (Adorno, 1973: 191, — first ed. 1949), can be considered as one of the earliest manifestations of such questioning. More recently, as an example, Makis Solomos writes, ,....one can ask oneself if, in opposition to the traditional definition, today, music would not be a new art of space rather than the art of time.“(Solomos, 1998: 213. ,...on peut se demander si, contrairement à sa définition traditionnelle, la musique ne serait pas, de nos jours, plutôt que l'art du temps, un nouvel art de l'espace."). 
The mechanism of embodied perception in tonal music is based on two fundamental systems: the system of tonal attractions and the system of regular meter. These systems create the ,environment" for all aspects of musical composition — from simple melodic and rhythmic elements to large-scale form. Note that both the systems of tonal attractions and meter are mutually coordinated and have a highly hierarchical organization: the hierarchy of tone and chord functions in harmony as well as in strong and weak beats in meter. Both systems are also tied to the basic sources of the embodied musical meaning: vocal expression and bodily motor actions (dance, walk, work, etc.).

In these conditions, the mimetic participation ${ }^{7}$ is mainly determined by embodied expectations, generated in the process of music unfolding through time. Music is experienced as a linear flow of affective gestural expression, based in the fundamental rhythms of the human organism - pulse and breathing. ${ }^{8}$ Spatial representations may of course accompany this process, and they can be indispensable while composing, performing or mentally representing music. However, they are not essential at the very elementary level of music making and perception. ${ }^{9}$

All these characteristics of temporal experience in tonal music correspond to what Jonathan Kramer (1988) described as ,goal-directed linear time“, with the caveat that Kramer's theory is based mainly on the cognitivist perspective and does not include the concept of embodied perception. This does not affect the validity of Kramer's musical analyses, however, but only the underlying explanation of music perception mechanisms.

The weakening of both tonal and metric systems, from the second half of the $19^{\text {th }}$ century, led progressively to disintegration of time linearity and, at the same time, an increase in the importance of musical space. To be clear, this includes quasigeometric space, space as substance, and potentially physical space, whereas the role of energetic space and large-scale space decreased, because in tonal music both are related to tonal gravity. We can observe this phenomenon in composers as different as Debussy, Stravinsky, Schönberg and his school, Ives, Varèse, etc., whose works paved the way toward the apex of this process in the post-Second World War avant-garde.

7 Cox defines mimetic participation as ,,a central source of musical affect“(Cox, 2016: 14); it „emphasizes the joining-in and taking-part that result from MMI and MMA.“ "For mimetic motor imagery and mimetic motor action - G.B.] (Cox, 2016: 15).

8 The relationship between meter and rhythm on the one hand, and pulse and breathing on the other, is very consistently theorized in two articles by the Swiss conductor and theorist Ernest Ansermet: „Les structures du rythme“ and „Le temps musical“ (Ansermet 1983: 135-149 \& 159-168).

9 Musical gravity and attraction at this level are experienced, but not ,seen“ mentally. When we speak about energetic space, we speak about mental vision, and not about immediate embodied experience of motion and attractions in the process of perception or performance. The same is true for quasi-geometrical space and space-substance. 
The disintegration of linearity concerns not only the „logic“ of musical grammar and formal principles, but also the perception of musical gesture, which loses its linear character as well as its communicative immediacy. Some compositional means still remain potential factors of direct empathy - for example, crescendos/decrescendos, accelerandos/ritardandos, progressive register changes, and other perceptible directional processes. Although, at the very level of musical language, the gestural empathy is restrained, and this leads to the switch of the main mechanism of expressive gesture perception from direct to mediated mode. The capacity of mental ,sight“, or the ability to picture quasi-spatial images of music becomes vital for meaningful perception. This is, in fact, one of the important aspects of ,intellectualization“ of music in avant-garde movements.

Trained musicians who are familiar with the avant-garde generally have a spontaneous spatial listening mechanism. However, through my lectures on the history of music and through my private contacts, I have met some sensitive and profound nonmusician listeners who were able to develop by themselves such a listening mechanism. Recently, for example, one of them exclaimed while discovering Evryali by Xenakis: „For me this is not music! This is plastic art... with sounds. As if I could see them..."

In my experience, highlighting the musical space phenomenon as a core of aesthetic perception is, in general, a very efficient method of familiarizing students with avant-garde composers' works.

\section{Musical space and gesture from Schönberg to post-Second World War avant-garde}

Now, let us turn our attention to the historical development of music from late Romanticism to Integral Serialism. Schönberg and his disciples strikingly intensified the expressive gesture of the romantic individualists, but, at the same time, they abolished tonal syntax and, to a large extent, rhythmical predictability. The result was the inhibition of direct ,in-time“" empathy and, despite very expressive musical „gesticulation“, a kind of ,alienation" of gesture. Thus, the expressive gesture migrated, so to say, from time to space. The mental quasi-spatial representation of music became an indispensable condition to perceive the embodied meaning of music, much more drastically than in most complex tonal works.

Since the expressive meaning in the Second Viennese School was carried via melodic lines and their combinations, the aesthetically and technically predominant role was played by quasi-geometric space. As an example, I shall quote Schönberg's Klavierstück Op. 11 No. 1, measures 12-16, (Ex. 3). I chose this excerpt because a quasi-spatial perception of passage shapes, layers, and sound events here becomes crucial, though the very beginning of this piece, despite its atonal design, still represents a linear singable melody with accompanying chords and contrapuntal voices. 
Of course, in measures 12-16, the perception of a dramatic succession and the dialogic interaction of events is very important too. However, in the absence of quasi-geometric vision, it cannot be sufficiently clear for a meaningful and evocative listening.
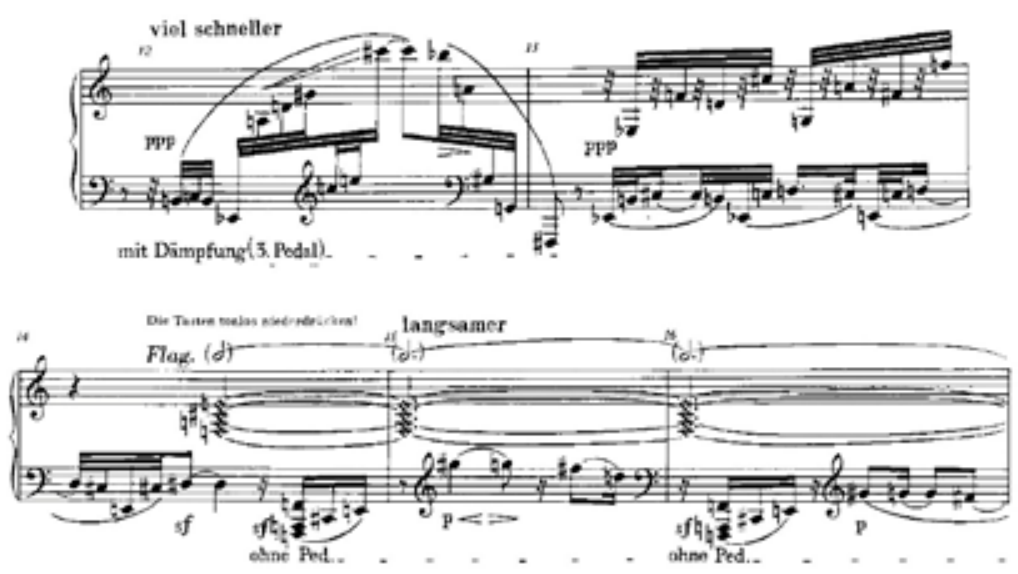

\section{Example 3. Arnold Schönberg: Klavierstück Op. 11 No. 1 (1909), m. 12-16.} https://vimeo.com/402230716

The shift from time to space in the Second Viennese School concerned not only the listener's perception, but also the composer's work and imagination. Schönberg's twelve-tone technique already involved, to a large extent, the spatial manipulation of pitches, and this tendency continued to increase with further developments toward Integral Serialism.

While Schönberg was still attached to the discursive model of music, Webern suspended the temporal dimension much more radically. His aphoristic style already leaned toward pointillism and spatial distribution in his free atonal period. Later, however, in his twelve-tone period, the ,spatialization“ expressed itself at a qualitatively new level. The minimization and concentration of the intervallic material and division of rows into symmetrical subgroups, typical of Webern's dodecaphonic technique, reduced the compositional process, in its essential part, to spatial permutations of small motivic cells. Consequently, the quasi-geometric musical space became more skeletal and abstract, and almost all the aesthetic substance of music, whether gestural or constructivist, was now ,imprinted“ in quasi-geometric space. The works like Symphony Op. 21 or the Concerto for Nine Instruments Op. 24 (Ex. 4) represent the unfolding in time of spatial sonorous geometries, which are totally imperceptible without an advanced ability to mentally „visualize“ the musical space. The listener must „see" the dislocated expressive melodic fragments while listening; otherwise, he will perceive just a cacophony. 
STUDIJE O MUZIČKOJ UMETNOSTI/STUDIES ON MUSIC
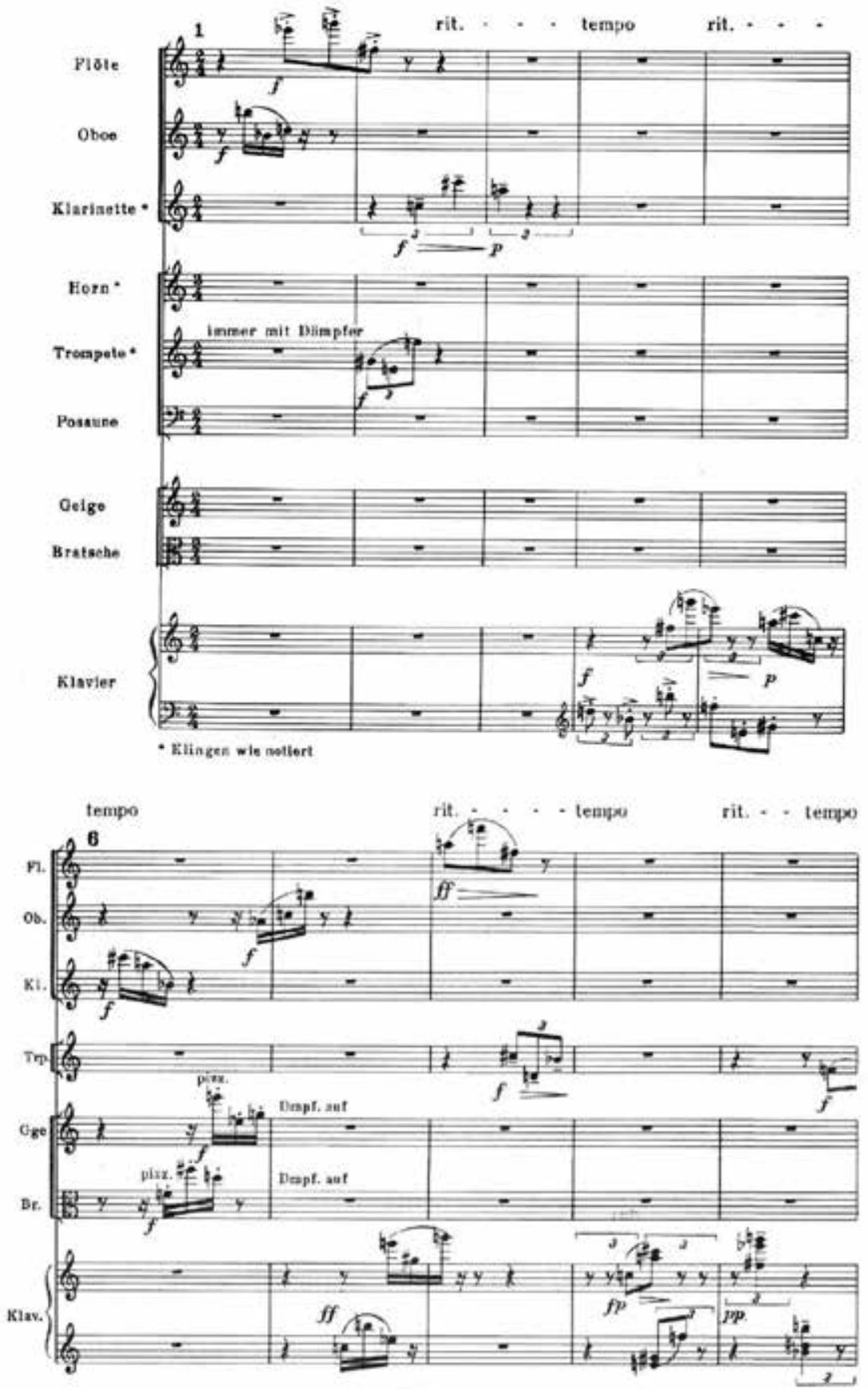

Example 4. Anton von Webern: Concerto for Nine Instruments Op. 24. https://vimeo.com/402232999 
What is important to notice is that even in the composer's most rigorously formal works, the Webernian musical gesture remains rooted in vocal subjective expression. As Ligeti has put it, in Webern's music ,remnants of 'expressive melody', if only fragments, are left hanging from the skeleton of the structure" (Ligeti, 1960: 53). These remnants of expressive melody are gestures at their core. They are genetically related to the romantic musical universe, and their embodied meaning almost always can be fully captured by means of vocal mimetic reproduction.

The next step, accomplished by postwar Integral Serialism, was the suppression of such inner vocal reference. In Webern's technique, the durations, intensities, and attacks were not totally predetermined by off-time abstract structures - rows, rotational squares, etc. Therefore, the concrete design of musical figures could still be controlled by direct creative intuition. By contrast, the serial control of all the parameters suppressed the free assignment of rhythms, dynamics, attack characteristics, etc. which resulted in a definitive disconnection between intervallic material and vocal expressivity.

The musical spaces produced by the structuring principles of Integral Serialism, which presuppose the total neutrality of twelve pitch-classes (,equal in rights“) and of all other sound parameters, could be only „cold“ and perfectly static, with a strong quasi-geometric quality. The expressive gesture was thus conceptually disabled, even if an absolute elimination of embodied perception of music is virtually impossible. ${ }^{10}$ However, as is well-known, this drastically formalistic moment of music history was short-lived. The most prominent avant-garde composers sought to overcome the rigidity of the serial method as early as the 1950 s. The most striking example is certainly that of Stockhausen. In Stockhausen's evolution through the 50s we can observe a constant complexification of the serial structuring methods, with which the composer endeavors not only to obtain a maximal integration of sound parameters, but, also, to achieve a control of global gestural shapes of sound constellations.

Given that gesture in Stockhausen's music is a vast topic, I cannot consider it here in detail. I shall limit myself to two examples: the Klavierstück I (1952) and Gruppen (1955-57). The Klavierstück I was presented by Stockhausen in 1955, in a radio talk, as an illustration of his concept of "group composition“. ${ }^{11}$ According to the composer, his concept serves as a link between the compositional work and perception - i. e. it allows people to compose and to perceive music on the basis of audible differences and affinities between groups. In his explanation, Stockhausen suggests

10 It is impossible, firstly, because of the existence of the performer's gesture, and secondly, because the perception of any sound is to some extent embodied. Few radical cases, like Cage's 4'33" or La Monte Young's Compositions 1960, here are not relevant.

11 This talk was published in the form of article „Group Composition: Klavierstück I (A Guide to Listening)“"(Stockhausen, 1963: 63-74). 
a listening attitude that clearly implies the perception of quasi-geometric space: „We experience the contours of the groups in a meaningful way: they are of different lengths, have different forms of movement, different densities and speeds; different sound forms" (Stockhausen, 1963: 66, emphasis in original). ${ }^{12}$ As Stockhausen argues, the sound forms should be impregnated in our memory with their salient characteristics, in order to be integrated into the overall image of a work. Moreover, the Stockhausenian descriptions of ,sound forms" at times clearly imply a perception of gestures encoded in musical space. The beginning of Klavierstück I, for example, is presented as a global wave-like shape with a complex ascending trajectory, peak, and descent (Ex. 5).

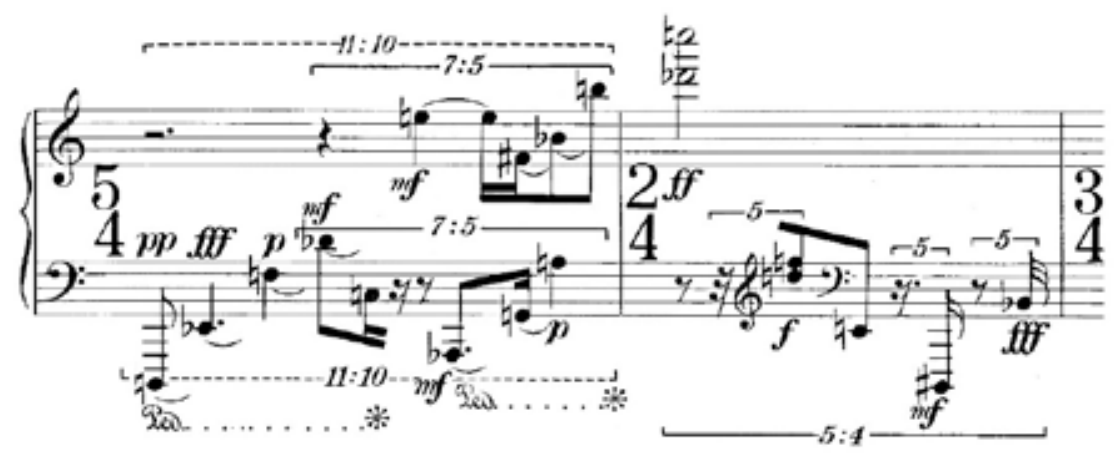

Example 5. Karlheinz Stockhausen: Klavierstïck I (1952), beginning. https://vimeo.com/402235070

In Gruppen for 3 orchestras - one of Stockhausen's major works - the gestural character of the small structural units is more palpable than in Klavierstück I. Compared to the monochrome and limpid texture of the piano piece, these units groups and their subdivisions (,formant-spectra“) — are much more colorful and dense. The very sophisticated serial organization of this piece, described in Stockhausen's famous text ,...How Time Passes...“, written in 1956 (Stockhausen, 1959), is entirely based on theoretical speculations that focus time structures, and not space. The music remains, however, fundamentally non-linear and the perceptive mode that it involves is based on quasi-spatial listening and the ,vision“ of SIMGs.

12 „Die Konturen der Gruppen erleben wir sinnfälig: sie sind verschieden lang, haben verschiedene Bewegungsformen, verschiedene Dichten und Geschwindigkeitsgrade; verschiedene Klangformen." 
STUDIJE O MUZIČKOJ UMETNOSTI/STUDIES ON MUSIC
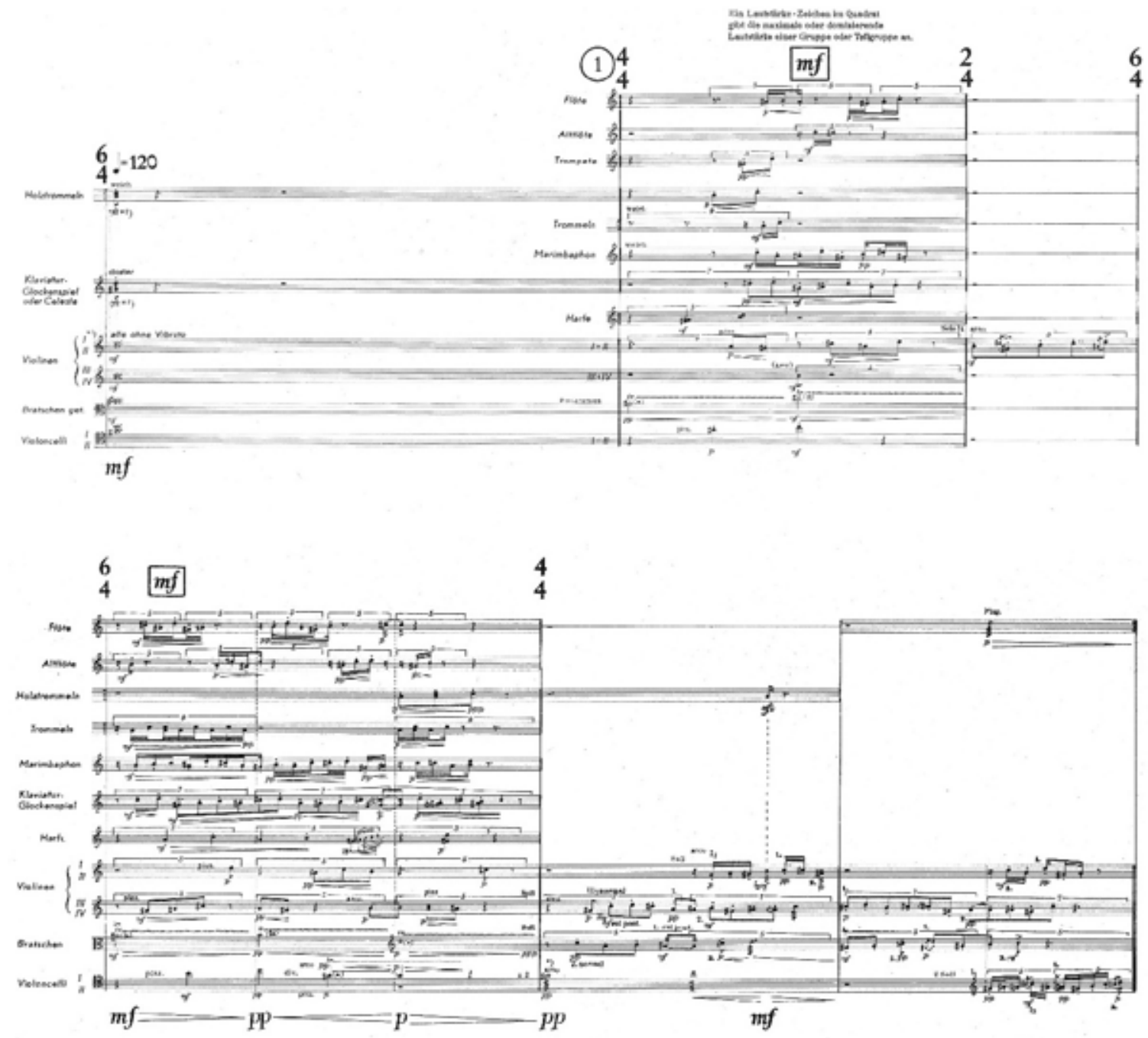

Example 6a. Karlheinz Stockhausen: Gruppen (1955-1957), opening measure and group No. 1.

https://vimeo.com/402237181 


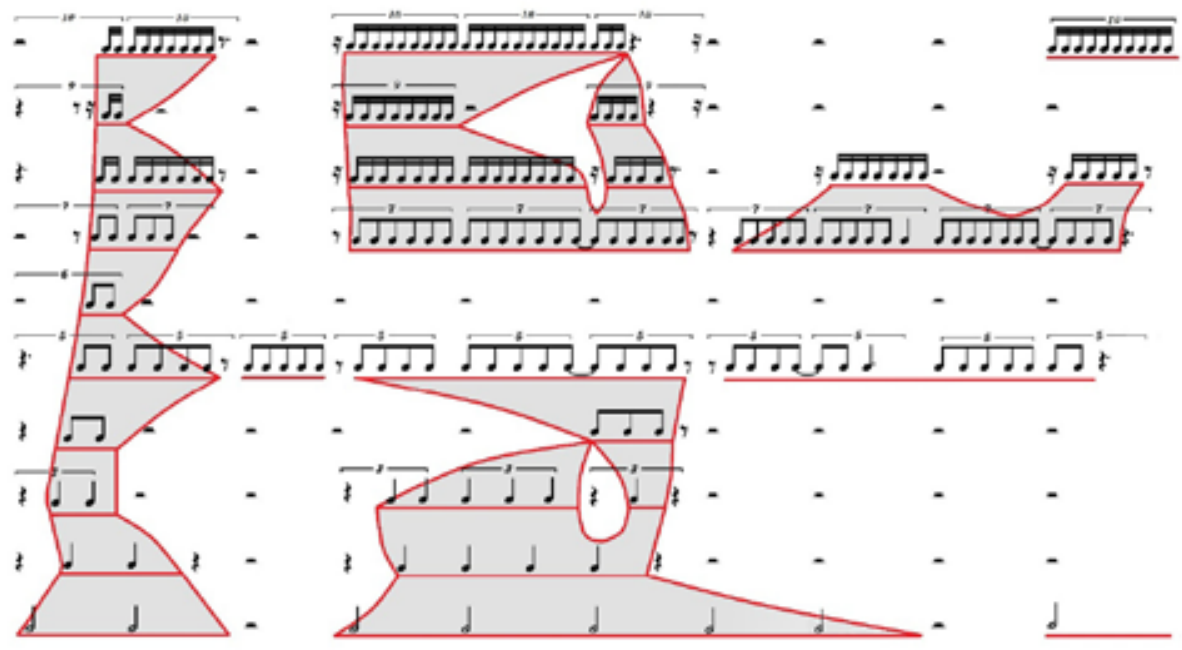

\section{Example 6b. Gruppen: rhythmical profile (,group-spectrum“) of group No. 1 with superimposed graphical representation.}

It should be noted that the gestures „encoded“ in Stockhausenian musical structures have nothing to do with vocal expression, nor with traditional sentimental or narrative meaning. In light of Stockhausen's philosophical views, their meaning could be broadly defined as representing an abstract game of spiritual forces of the Universe, experienced as an immense extension of the composer's subjective interiority.

Among the most original composers of the postwar decades, I should also mention Xenakis and Ligeti. Unlike the defenders of serialism, they developed compositional techniques focused on sound substance. Ligeti's techniques are typically orientated toward associations with color and lighting effects, while Xenakis highlights mostly physical qualities of sound masses, such as density, viscosity, granularity, fluidity, and internal turmoil. In Ligeti's music we find some pure examples of SIMG expressed as progressive changes of global sound color (Ex. 7). In contrast, Xenakis's sound masses generally contain elementary gestures as inner components of sound substance (Ex. 8). ${ }^{13}$

13 I do not consider here all forms of manifestation of gesture in Xenakis's and Ligeti's works, but only those, which are related specifically to sound-as-substance. 


\section{Example 7 (sound only). György Ligeti: Atmosphères for large orchestra (1961), from letter $\mathrm{G}$ to $\mathrm{L}$ of the score \\ https://vimeo.com/402244646}

\section{Example 8 (sound only). Iannis Xenakis: Pithoprakta for string orchestra, two trombones, xylophone, and wood block (1955-56), m. 122-186. \\ https://vimeo.com/402248349}

It also must be emphasized that Ligeti's and Xenakis's works raise the question of the embodied perception of sound itself, without any gestural profile. Because for both composers, the sound substance has its proper quasi-material qualities (color, lighting, density, viscosity, granularity...), which have a fundamental aesthetic importance and which are experienced in an embodied way.

The format of this paper does not allow me to get into this problem. For now, I will simply point out that Xenakis's and Ligeti's works contain striking examples that demonstrate the need for a theoretical differentiation of embodiment as a broader concept, and for gesture as a particular manifestation of embodiment. One may argue that any embodied meaning necessarily goes back to some gestural experience. Even so, the sound substance itself is of an essentially static nature, i. e. it does not fall under the definition of gesture as an „energetic shaping through time“ and thus it should be considered a separate thing. A model for such a differentiation exists in Pierre Schaeffer's Treatise on Musical Objects (Schaeffer, 2017), first published in 1966, in which Schaeffer introduces the concepts of form and matter, as characteristics of a sound object. In fact, this pair of concepts is to a large extent congruent with my concepts of quasi-geometric space and space-as-substance. ${ }^{14}$

\section{„Spatialization“ of musical gesture: psychological background of the historical process}

Finally, let us consider the global tendency to shift the aesthetic centre of gravity from direct to mediated gesture in avant-garde art music from a philosophical and psychological standpoint. The process of „spatialization“ of music is expressed in different ways in almost all avant-garde composers' works. Regardless of concrete styles, this process includes a suspension of linearity — or, at least, of goal-directed linearity, - a decrease in the communicative immediacy of music, and a reversal of

14 Some studies on the embodied perception of sound were undertaken recently. For example Wallmark \& al. (2018) investigated the embodied perception of „noisy“ timbres in music. The concept of timbre is, however, more narrow than that of sound substance. The latter includes also complex textures that we perceive as integrated matter. 
the expressive gesture perception from the direct to the spatially mediated mode. In general, these processes are explained as consequences of the inner evolution of musical language itself, or of the „emancipation“ of sound or parameters, and so on. However, in my opinion, we should also consider them as psychological consequences of cultural trauma. This trauma consists of the distrust of human communion and cathartic consolation through direct empathy, or, more broadly, in a distrust of Humanism, or a distrust of what Erich Fromm (1976) called „The great promise“. ${ }^{15}$ The history of this trauma, marked by two terrible World Wars, can be traced back to the second half of the $19^{\text {th }}$ century. The underlying factors include the development of mass manipulation, the decline of humanist aspirations, the evaporation of sociability, and the disintegration of spiritual unity of society.

The goal-directed linearity of tonal music emerged during the transition between the Renaissance and Baroque eras, resulting from the musical imitation of human passions, or of direct emotional expression based on oral language. Music then imitated gestural and rhetorical features of the expressive poetic discourse, and this made music capable of expressing human affective interiority. Beforehand, complex human emotional processes could be communicated essentially through lyrics, but not by means of purely musical resources. In this sense, the music of $17^{\text {th }}-19^{\text {th }}$ centuries could be regarded as a fundamentally humanistic art.

Since the beginning of the modernist period, the most advanced musical movements expressed several mutually related tendencies, including the suspension of time linearity and the valorization of musical space, the rejection of verbal language as a model of musical language, and the distancing or even the repression of gestural immediacy. The reason that these processes were interdependent is because the model of tonal music was principally not the verbal language itself, but the prosody and paralinguistic stream that accompany verbal language, i. e. not grammar and rational signification, but intonation and gesture. The distrust of human affective communication and community, one of the significant components of the crisis of Humanism, resulted in the rejection of gestural immediacy in music, and in the erection of a communication barrier - a sort of protection of high art's purity. Another important element related to gestural immediacy was that references to dance music underwent the same fate: they progressively disappeared from avant-garde music as a palpable reference. In these conditions, the art music became more and more „cryptic“, and one of the most important keys to understand such its message was the ability to hear music in a quasispatial mode.

15 ,The great promise“ consists of happiness, freedom, and abundance that should be reached due to progress, understood in a material way. 
Significantly, the most radical and conceptually pure models of music centered around quasi-geometric space, space-substance, and SIMG, were produced during the 1950s and early 60s. With the end of musical modernism and the beginning of the postmodern era, other tendencies gained prominence, such as theatricalisation (including that of gesture), pastiche and quotation, open form, irony, stylistic plurality, minimalism, and the restoration of old idioms, etc. The modernistic paradigms, however, continued to exist and to interact with them.

The very general theoretical frame that I have outlined here is to be developed and verified in more narrow historical and theoretical studies as well as in pedagogical use. It can contribute not only to the development of musical gesture studies, but also to the understanding of today's climate in musical creation.

\section{REFERENCES:}

1. Adorno Theodor W. 1973. Philosophy of Modern Music. Translated by Anne G. Mitchell and Wesley V. Bloomster. London: Sheed \& Ward.

2. Ansermet, Ernest. 1983. Ecrits sur la musique. Neuchâtel: Éd. de la Bacconière.

3. Bériachvili, Georges. 2018. „Teoriya intonacii i issledovaniya o muzykal'nom zheste: perspektivy vzaimodejstviya i sinteza." [„,Theory of Intonation and Musical Gesture Studies: Perspectives of Interaction and Synthesis."] Iskusstvo muzyki. Teoriya i istoriya [Art of Music. Theory and History], 18, 131-178. [In Russian] http://imti.sias.ru/upload/iblock/335/imti $2018 \quad 18131 \_178$ beriachvili.pdf

4. Bériachvili, Georges. 2013. „L'intonation et le geste expressif: de l'héritage d'Assafiev vers une théorie générale de l'expression artistique." In Topicality of Musical Universals / Actualité des Universaux musicaux. Additional contributions. Edited by Jean-Luc Leroy, 12-32. http://www. trans-mut.fr/ressource/universals-files/pdf/7c. $\% 20 \mathrm{MU} \% 20 \mathrm{WEB} \% 20$ Additional $\% 20$ contributions. pdf

5. Bériachvili, Georges. 2010. L'espace musical: concept et phénomène. A travers l'avant-garde des années 1950-60 (Stockhausen, Xenakis, Ligeti...). PhD thesis. University of Rouen, 302 p.

6. Bériachvili, Georges. 2009. „L'espace musical chez K. Stockhausen et I. Xenakis: phénoménologie et implications esthétiques (Klavierstück I et Herma).“ Education musicale, 563, $35-41$.

7. Cox, Arnie. 2016. Music and Embodied Cognition: Listening, Moving, Feeling, and Thinking. Bloomington: Indiana University Press.

8. Fromm, Erich. 1976. To have or to be? New York: Harper \& Row.

9. Hatten, Robert S. 2018. A Theory of Virtual Agency for Western Art Music. Bloomington: Indiana University Press.

10. Hatten, Robert S. 2004. Interpreting Musical Gesture, Topics, and Tropes: Mozart, Beethoven, Schubert. Bloomington: Indiana University Press.

11. Imberty, Michel. 2005. La musique creuse le temps. De Wagner à Boulez : Musique, psychologie, psychanalyse. Paris: L'Harmattan.

12. Kramer, Jonathan D. 1988. The Time of Music: New Meanings, New Temporalities, New Listening Strategies. New York: Schirmer Books.

13. Ligeti, Gyorgy. 1960. „Pierre Boulez: decision and automatism in Structure Ia.“ Die Reihe, 4, 36-62. 
14. Lochhead, Judy. 2019. „Review-Essay on Suzannah Clark and Alexander Rehding, eds., Music in Time: Phenomenology, Perception, Performance (Harvard University Press, 2016).“ Music Theory Online, 25(4). Retrieved May 2, 2020 from the World Wide Web https://www.mtosmt.org/ issues/mto.19.25.4/mto.19.25.4.lochhead.html?fbclid=IwAR2O2N8vBtOZDyg1E4GK39G7j817v0xxtHmCC-AWsfsrTyYpSID16dF8qc

15. Schaeffer, Pierre. 2017. Treatise of Musical Object. Translated by C. North and J. Dack. Oakland, California: University of California Press.

16. Smith, David W. 2018. „Phenomenology.“ In The Stanford Encyclopedia of Philosophy. Edited by Edward N. Zalta. Retrieved March 10, 2020 from the World Wide Web https://plato.stanford.edu/ archives/sum2018/entries/phenomenology/

17. Solomos, Makis. 1998 „L'espace-son.“ In L'Espace: Musique/Philosophie. Edited by Jean-Marc Chouvel and Makis Solomos, 211-224. Paris: L'Harmattan.

18. Stockhausen, Karlheinz. 1959. ,...How Time Passes...“ Die Reihe, 3, 10-40.

19. Stockhausen, Karlheinz. 1963. Texte zur elektronischen und instrumentalen Musik. Vol. I, Köln: DuMont-Buchverlag.

20. Wallmark, Zachary \& Iacoboni, Marco \& Deblieck, Choi \& Kendall, Roger A. 2018. „Embodied Listening and Timbre Perceptual, Acoustical, and Neural Correlates." Music Perception: An Interdisciplinary Journal, 35(3), 332-363.

\section{Muzički gest i fenomenologija muzičkog prostora u avangardnoj muzici 20. veka}

Apstrakt: Ovaj rad predlaže konceptualni okvir koji uspostavlja vezu između dva osnovna koncepta muzičke teorije: muzičkog gesta i muzičkog prostora.

Odvijanje u vremenu je osnovna karakteristika muzičkog gesta. Međutim, u plastičnim umetnostima gest je predstavljen samo u prostornom obliku. Pošto muzika poseduje svoj unutrašnji prostor, logično je pretpostaviti da muzički prostor može nositi i oprostorene gestovne „otiske“. Da bi se opisalo takvo indirektno manifestovanje gesta, autor uvodi koncept prostornog otiska muzičkog gesta (SIMG). Ovaj koncept podrazumeva fenomenološki pristup muzičkom prostoru, u skladu sa kojim fenomen muzičkog prostora uključuje sve oblike kvaziprostornih mentalnih reprezentacija same muzike, i isključuje sve apstraktne reprezentacije kao što su prostor između tonskih visina, prostor vrednosti parametara, šeme formalne strukture, itd.

Izdvaja se pet opštih aspekata fenomena muzičkog prostora:

- Kvazigeometrijski prostor: mentalni prikaz muzike, zasnovan na analitičkoj prostornoj viziji njegovih elemenata (zvukova, slojeva, figura, oblika, itd.).

- Prostor kao zvučna supstanca: povezanost zvuka s bojom, svetlošću, materijalom, fizičkim svojstvima supstanci, itd.

- Energetski prostor: kvaziprostorni prikaz sila koje deluju u muzičkom procesu.

- Sintetički vremenski prostor velikih razmera.

- Fizički prostor. 
Ove vrste prostornih prikaza uglavnom koegzistiraju, ali jedan od njih može steći vodeću ulogu u određenim stilovima. U razvoju umetničke muzike tokom prošlog veka, prioritet je bio na trima komponentama: kvazigeometrijskom prostoru, prostoru kao supstanciji i fizičkom prostoru. Citirajući dela Šenberga, Veberna, Štokhauzena, Ksenakisa i Ligetija, autor razmatra neke paradigmatične primere u kojima SIMG postaje ključni element, posmatrano s tehničkog i estetskog stanovišta.

U poslednjem delu rada, izlaže se hipoteza prema kojoj bi proces „spacijalizacije“ muzike i „migracije“ gesta u muzički prostor mogao biti rezultat kulturne traume. Ta se trauma sastoji od nepoverenja u ljudsko zajedništvo i katarzičnu utehu putem direktne empatije ili, šire rečeno, nepoverenja u humanizam.

Ključne reči: muzički gest, muzički prostor, otelovljenje muzičke spoznaje, muzika avangarde, muzičko vreme (linearnost/nelinearnost). 